\title{
Studi Kerentanan Airtanah Terhadap Pencemaran dengan Menggunakan Metode Drastic Pada Cekungan Airtanah (CAT) Karanganyar-Boyolali, Provinsi Jawa Tengah
}

\author{
Thomas Triadi Putranto ${ }^{1}$, Rinal Khaidar Ali ${ }^{1}$, dan Aji Bagas Putro ${ }^{1}$ \\ 1Departemen Teknik Geologi Fakultas Teknik Universitas Diponegoro; e-mail: putranto@ft.undip.ac.id
}

\begin{abstract}
ABSTRAK
Cekungan Airtanah (CAT) Karanganyar-Boyolali merupakan CAT yang terletak di Jawa Tengah yang terdiri dari Kota Surakarta, Kabupaten Semarang, Kabupaten Boyolali, Kabupaten Klaten, Kabupaten Karanganyar, Kabupaten Sragen, dan Kabupaten Wonogiri dengan luasan CAT sebesar $3.877 \mathrm{~km}^{2}$. Penelitian ini memiliki tujuan menganalisis kerentanan airtanah terhadap pencemaran secara spasial. Penilaian kerentanan airtanah terhadap kontaminan dapat diketahui dengan menggunakan metode DRASTIC. Metode DRASTIC merupakan metode pembobotan dari hasil berbagai macam parameter diantaranya yaitu : Kedalaman muka airtanah (D), Recharge (R), Media akuifer (A), Media tanah (S), Topography (T), Zona vadoze (I), dan Konduktivitas hidrolika (C).Dari hasil tumpeng tindih pembobotan setiap parameter, nantinya akan dijumlahkan untuk mendapatkan nilai rentang DRASTIC Indeks. Berdasarkan hasil analisis didapatkan rentang nilai DRASTIC Indeks (DI) dari 86-148 yang dibagi dalam empat tingkat kerentanan. Tingkat kerentanan sangat rendah memiliki nilai DI 86-100 dimana pada kerentanan sangat rendah memiliki sifat tidak memungkinkan terjadinya kontaminasi pencemaran. Daerah tingkat kerentanan sangat rendah memiliki nilai DI 101-120 dimana pada tingkat kerentanan ini memiliki sifat dapat tercemar dengan intensitas kecil dikarenakan pembuangan sebagian kecil polutan yang dilakukan secara berkala. Daerah tingkat kerentanan sedang memiliki nilai DI 121-140 dimana memiliki sifat dapat tercemar oleh sebagian polutan yang dibuang secara terus-menerus. Daerah tingkat kerentanan tinggi memiliki nilai DI 141-148 dimana pada tingkat pencemaran ini memiliki sifat dapat tercemar oleh semua polutan, kecuali memerlukan daya serap yang tinggi dan mudah berubah dengan berbagai macam skenario.
\end{abstract}

Kata kunci: Metode DRASTIC, Cekungan airtanah, DRASTIC indeks, Kerentanan airtanah

\begin{abstract}
Karanganyar-Boyolali Groundwater Basin (CAT) is located in Central Java Province across Surakarta City, Semarang Regency, Boyolali Regency, Klaten Regency, Karanganyar Regency, Sragen Regency, and Wonogiri Regency with a total area of $3,877 \mathrm{~km}^{2}$. This study aims to analyze groundwater vulnerability to spatial pollution. Assessment of groundwater vulnerability to contaminants can be determined using the DRASTIC method. The DRASTIC method is a weighting method of the results of various kinds of parameters including Groundwater Depth (D), Recharge (R), Aquifer Media (A), Soil Media (S), Topography (T), Vadose Zone (I), and Conductivity hydraulics (C). From the results of the overlying weighting of each parameter, it will be summed to conduct the value of the DRASTIC Index range. Based on the results of the analysis it was found that the range of the DRASTIC Index (DI) from 86-148which was divided into four levels of vulnerability. The very low level of vulnerability has a value of DI 86-100 which indicating no potential of groundwater vulnerable to contamination occur. The low level of vulnerability has a value of DI 101120 where at the level of vulnerability it can be polluted with small intensity due to the regular disposal of a small number of pollutants. The area of moderate vulnerability has a value of DI 121-140 which has properties that can be polluted by some pollutants which are continuously disposed of. The area of high vulnerability has DI value 141-148 which at the level of pollution has the property of being polluted by all pollutants, except that it requires high absorption capacity and is easy to change with various scenarios.
\end{abstract}

Keywords: DRASTIC method, Groundater basin, DRASTIC index, Groundwater vulnerability

Citation: Putranto, T.T., Ali, R.K.,dan Putro, A.B.(2019). Studi Kerentanan Airtanah terhadap Pencemaran dengan Menggunakan Metode DRASTIC pada Cekungan Airtanah (CAT) Karanganyar-Boyolali, Provinsi Jawa Tengah. Jurnal Ilmu Lingkungan, 17(1), 158171, doi:10.14710/jil.17.1.158-171 


\section{Latar Belakang}

Cekungan Airtanah (CAT) KaranganyarBoyolali merupakan suatu cekungan yang mencakup beberapa kota dan kabupaten yang membentang dari bagian tengah hingga bagian selatan Provinsi Jawa Tengah. Kota dan kabupaten yang melingkupi CAT Karanganyar-Boyolali yaitu Kota Surakarta, Kabupaten Boyolali, Kabupaten Klaten, Kabupaten Sukoharjo, Kabupaten Karanganyar, Kabupaten Sragen, dan Kabupaten Wonogiri (Gambar 1). Menurut Permen ESDM no 2 Tahun 2017 tentang cekungan airtanah bahwa luas CAT Karanganyar-Boyolali memiliki luasan $3.877 \mathrm{~km}^{2}$.

Pemanfaatan airtanah sebagai kebutuhan harus sesuai dengan konsep berwawasan lingkungan dan sesuai dengan keseimbangan dan kelestarian airtanah (Foster dan Hirata, 1988; Danaryanto, 2005) agar tidak terjadi kelangkaan akibat sumber yang tersedia berkurang atau terjadinya pencemaran; sehingga tidak dapat dimanfaatkan kembali. Tujuan penelitian inimenganalisis zona kerentanan airtanah terhadap pencemaran secara spasialdengan menggunakan metode DRASTIC (groundwater Depth, amout of Recharge, Aquifer type, Soil type, Topography, Impact of unsatuated zone, hydraulic Conductivity). Studi terkait kerentanan airtanah sudah banyak dilakukan oleh beberapa peneliti (Aller et al. 1987; Stempvort et al. 1993; Gogu dan Dassargues, 2000; Harter dan Walker, 2001; Ferreira, 2005; Hadi, 2006; Widyastuti dkk., 2006; Hatori, 2008; Civita, 2010; Pacheco et al. 2015; Yuslihanu 2015; Ananda, 2016; Kesuma, 2017; Rahaningmas, 2017). Penelitian kerentanan tersebut sebagian besar menggunakan wilayah administrasi sebagai batas penelitian tidak menggunakan konsep cekungan airtanah.

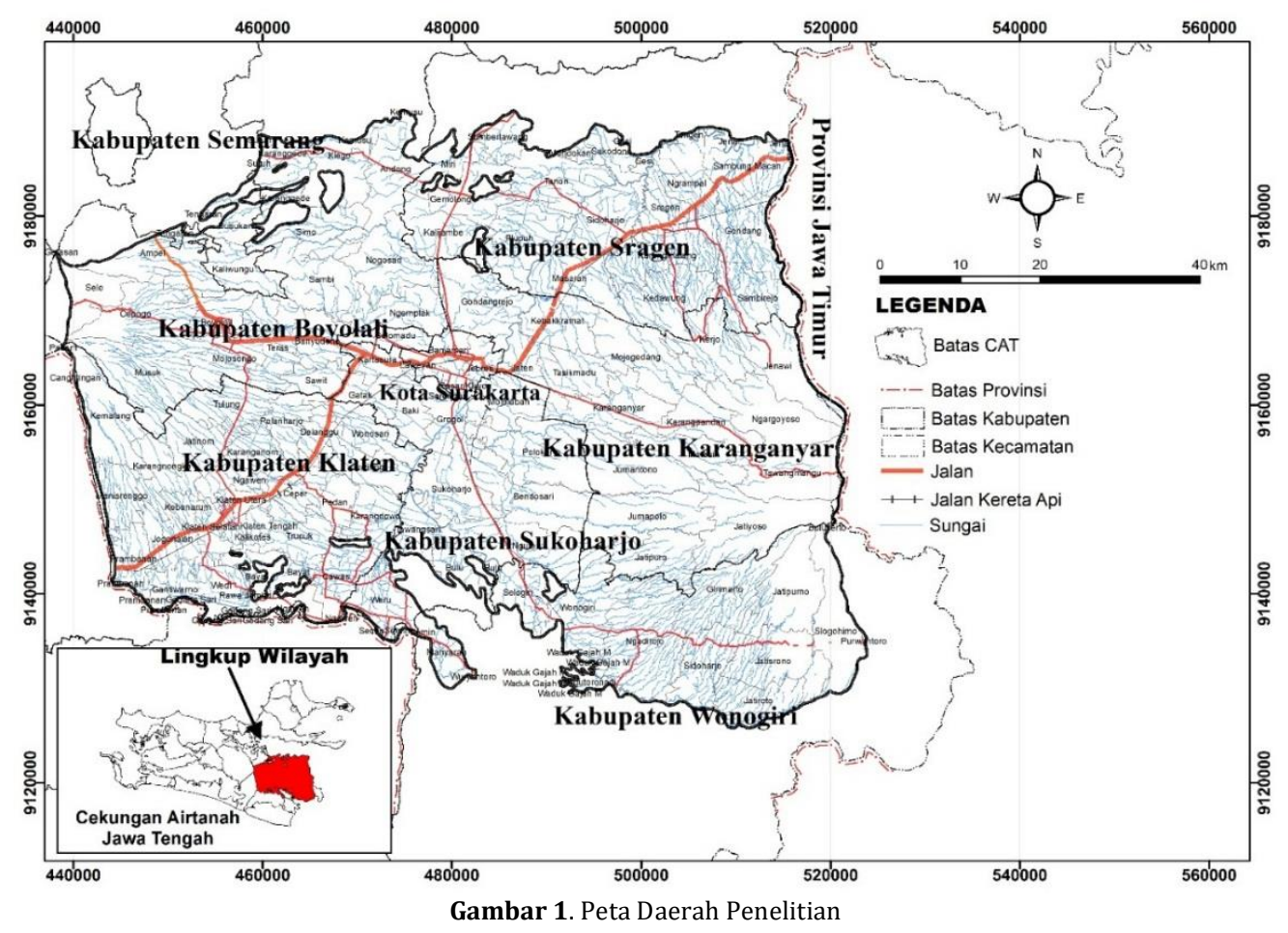

\section{Geologi Regional}

Berdasarkan pada peta geologi regional lembar Surakarta-Giritontro (Surono, dkk., 1992), lembar Ponorogo (Sampurno dan Samodra, H., 1997), dan lembar Salatiga (Sukardi dan Buditrisna,1992) dapat diketahui kondisi geologi yang menyusun pada daerah penelitian terdiri atas batuan dari hasil aktivitas vulkanisme (Gambar 2). Urutan stratigrafi daerah penelitian dapat dijabarkan menjadi beberapa satuan formasi dari tua ke muda diantaranya yaitu Batuan Malihan (KTm), Formasi Gamping Wungkal (Tew), Formasi Mandalika (Tomm), Formasi Kebobutak (Tomk), Andesit (Tma), Formasi Semilir (Tms), Formasi Kerek (Tmk), Formasi Nampol (Tmn), Formasi Wonosari (Tmwl), Formasi Kalibeng (Tmpk), Anggota Klitik
Formasi Kalibeng (Tpkk), Formasi Pucangan (Qpp), Formasi Kabuh (Qpk), Formasi Notopuro (Qpn), Tufa Jobolarangan (Qvjt), Breksi Jobolarangan (Qvjb), Endapan Gunung Merapi Tua (Qmo), Lava Sidoramping (Qvsl), Lava Jobolarangan (Qvjl), Batuan Gunungapi Lawu (Qvl), Lava Condrodimuko (Qvcl), Lahar Lawu (Qlla), Lava Sumbing (Qls), Batuan Gunungapi Takterpisahkan (Qvm), Endapan Undak (Qt), dan Aluvium (Qa).

\section{Hidrogeologi Regional}

Cekungan airtanah dibatasi oleh batasbatas hidrogeologi, batas-batas tersebut menunjang terjadinya proses hidrogeologisseperti pengimbuhan airtanah, pengaliran airtanah, dan pelepasan airtanah. Menurut Djaeni (1982) dalam 
Peta Hidrogeologi Indonesia lembar Yogyakarta, keterdapatan airtanah pada daerah CAT Karanganyar-Boyolali dapat dibedakan menjadi 3 kriteria yaitu akuifer dengan mengikuti ruang antar butir yang memiliki produktivitas airtanah tinggi, kemudian akuifer dengan aliran melalui celahan dan ruang antar butir, dimana pada daerah iniakuifer memiliki produktivitas airtanah tinggi tersebar di kaki gunung, dan akuifer bercelah dengan produktivitas kecil.

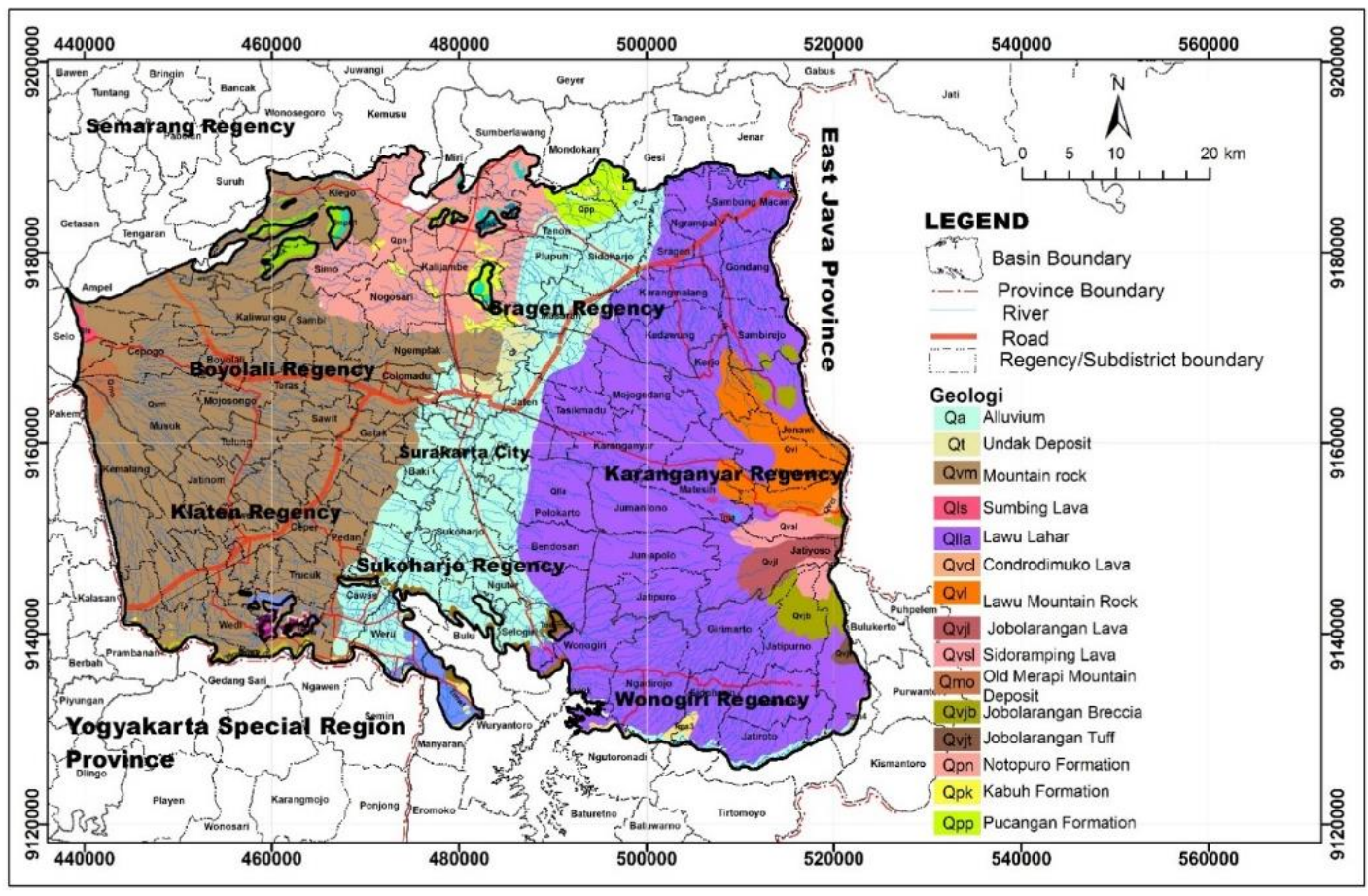

Gambar 2. Peta Geologi Regional Daerah Penelitian

\section{Kerentanan Airtanah}

Kerentanan airtanah merupakan kemampuan suatu airtanah dalam bertahan terhadap polusi dan kontaminan pada permukaan tanah sampai dengan muka airtanah atau pada daerah akuifer (Harter dan Walker, 2001). Menurut Ferreira (2005) dalam membendakan antara kerentanan terhadap pencemaran dengan risiko pencemaran, apabila risiko pencemaran tidak hanya dikontrol oleh satu jenis pengontrol saja yang bersifat statis melainkan ada faktor lain sebagai sumber pencemaran yang bersifat dinamis,sehingga risiko pencemaran dapat dipengerahui oleh 2 faktor tersebut yaitu polutan serta infiltrasi mencapai zona jenuh air. Dengan demikian dapat diartikan bahwa apabila suatu daerah memiliki kerentanan yang cukup tinggi namun risiko pencemarannya rendah hal ini dikarenakan pada daerah tersebut sumber pencemar yang menghasilkan polutan memiliki jumlah yang rendah.

\section{Metode DRASTIC}

Metode DRASTIC ini menekankan pada kondisi hidrogeologi yang mempengaruhi suatu pergerakan airtanah dan metode ini digunakan untuk mengetahui kerentanan airtanah dengan cakupan wilayah yang cukup luas. Pada metode ini ada 2 hal sebagai pokok dalam pengerjaannya yaitu didasari oleh kondisi hidrogeologi dan penggabungan parameter-parameter yang mempengaruhi terjadinya pencemaran pada airtanah. Berikut merupakan penjabaran dari metode DRASTIC yaitu:

\section{D : Depthto Water Table}

Faktor yang berpengaruh sebelum air menyentuh masuk ke muka airtanah, dikarenakan zat pencemar akan melewati tebal lapisan diatas muka airtanah tersebut. Apabila jarak muka airtanah cukup dalam maka potensi zat pencemar akan semakin kecil, sebaliknya apabila jarak muka airtanah cukup dangkal maka potensi airtanah untuk tercemar akan cukup besar peluangnya.

\section{$\mathbf{R}$ : Nett Recharge}

Nett Recharge merupakan gambaran dari jumlah airtanah yang terserap ke dalam tanah dan masuk mencapai muka airtanah. Recharge dapat membantu masuknya zat pencemar secara vertikal masuk menuju ke muka airtanah dan terjadi secara horizontal pada daerah akuifer. Apabila jumlah recharge yang masuk ke dalam tanah semakin besar, maka kontaminan zat pencemar yang terbawa akan memiliki jumlah yang besar pula. Begitu juga sebaliknya apabila recharge yang masuk kedalam tanah sedikit, maka kontaminan zat pencemar yang terbawa masuk juga akan memiliki jumlah yang sedikit. 
Dalam memperoleh nilai recharge menggunakan rumus

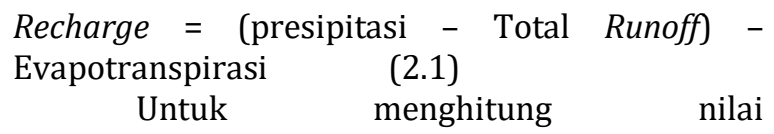

Evapotranspirasi/E $E_{t}$ digunakan rumus sebagai berikut (Turc 1954 dalam Putranto 2013):

$$
E_{t}=\frac{p}{\sqrt{0,9+\left(\frac{P^{2}}{\left(300+25 * T+0.05 * T^{3}\right)^{2}}\right)}}[\mathrm{mm} / \text { tahun }](2.2)
$$

Dimana: P: Presipitasi

\section{A : Aquifer Media}

$$
\text { T: Temperatur }
$$

Media akuifer juga memiliki peranan penting, dimana dalam hal ini mempengaruhi jumlah material yang terkontaminasi pada daerah permukaan dalam menembus lapisan akuifer. Arah dan rute zat pencemar akan mengalir tergantung media akuifer, biasanya dilihat dari keadaan di lapangan seperti halnya rekahan, permeabilitas, dan porositas. Semakin besar kemampuan akuifer dapat menahan laju zat pencemar/kontaminan maka potensi airtanah tercemar maka akan semakin kecil.

\section{S :SoilMedia}

Tanah memiliki peranan yang penting dari dampak yang ditimbulkan akibat pergerakan jumlah recharge air yang bergerak masuk melewati permukaan tanah hingga mencapai muka airtanah dan juga mengontrol kadar jumlah polutan yang masuk kedalam tanah bersama jumlah recharge air yang masuk. Ketebalan tanah juga mempengaruhi kegiatan terjadinya kontaminasi, semakin tebal suatu lapisan tanah maka akan berdampak juga pada waktu kontaminasi menuju ke muka airtanah termasuk pada kegiatan filtrasi, biodegradasi, sorpsi, dan volatilasi secara signifikan. Semakin tebal kondisi lapisan tanah maka akan semakin lama waktu tempuh untuk mencapai ke daerah jenuh air.

\section{T: Topography}

Topografi merupakan parameter yang dilihat berdasarkan kelerengan suatu daerah. Pada setiap daerah tentunya akan memiliki kelerangan yang berbeda-beda pula. Topografi dapat membantu atau menahan suatu zat tercemar pada daerah permukaan. Apabila kondisi kelerangan semakin curam, maka berpeluang aliran runoff akan semakin besar, sehingga aliran air permukaan yang terkontaminasi oleh zat pencemar/kontaminan yang meresap kedalam tanah dan yang akan sampai pada daerah akuifer/muka airtanah juga akan berkurang. Namun, apabila suatu daerah dengan kondisi permukaan yang landai akan membuat air yang terkena polutan akan menggenang dan mengakibatkan potensi air yang terkontaminan tersebut masuk kedalam tanah dan menuju ke lapisan muka airtanah/akuifer akan semakin besar peluangnya untuk mencemari muka airtanah tersebut.
Pada daerah zona tidak jenuh air dapat ditentukan dari karakteristik material, yang meliputi jenis dan batas tanah serta batuan yang terdapat di bawah muka airtanah. Material tersebut yang nantinya akan disebut media. Nantinya, media tersebut akan mengontrol arah dan panjang lintasan yang mengakibtakan terjadinya pengurangan waktu dan kuantitas material yang dimiliki juga akan berkurang. Kondisi arah lintasan akan bergantung pada banyaknya rekahan yang ada, selain itu juga dapat dipengaruhi oleh permeabilitas tanah, dan juga kedalaman suatu muka airtanah.

\section{C :Hydraulic Conductivityof The Aquifer}

Konduktivitas hidrolika merupakan suatu kemampuan material akuifer untuk dapat mengalirkan air dan mengontol suatu kecepatan pada aliran airtanah yang nantinya aliran airtanah tersebut akan mengalir akibat pengaruh dari gradien hidrolika. Konduktivitas hidrolika sendiri juga dikontrol oleh jumlah dan hubungan atau ruang antar akuifer ataupun ruang/rekahan antara suatu bidang perlapisan. Apabila konduktivitas hidrolika suatu batuan semakin besar maka kontaminasi yang terjadi akan besar pula.

Dalam metode DRASTIC ini terdapat 3 pembagian yang sangat penting yaitu weight, rating, dan ranges dimana akan didapatkan tingkatan nilai kerentanan airtanah terhadap pencemaran yang dapat dilihat dari hasil penjumlahan nilai masing-masing skor dari setiap parameter yang dihasilkan dari metode DRASTIC yang akan disebut DRASTIC Index.

DRASTIC Index =

$\mathrm{D}_{\mathrm{R}}{ }^{*} \mathrm{D}_{\mathrm{W}}+\mathrm{R}_{\mathrm{R}} * \mathrm{R}_{\mathrm{W}}+\mathrm{A}_{\mathrm{R}} * \mathrm{~A}_{\mathrm{W}}+\mathrm{S}_{\mathrm{R}}{ }^{*} \mathrm{~S}_{\mathrm{W}}+\mathrm{T}_{\mathrm{R}} * \mathrm{~T}_{\mathrm{W}}+\mathrm{I}_{\mathrm{R}}{ }^{*} \mathrm{I}_{\mathrm{W}}$ $+\mathrm{C}_{\mathrm{R}}{ }^{*} \mathrm{C}_{W}$ (2.3)

Dimana: R :Rating/Nilai

\section{$\mathrm{W}:$ Weight/Bobot}

Dari berbagai macam parameter tersebut nantinya akan dihasilkan bobot yang akan berpengaruh terhadap besarnya kontaminasi. Selain bobot, nantinya akan ada kelas atau rating pada setiap parameter. Nilai bobot tersebut akan dimulai dari lima (5) dimana kondisi tersebut dinyatakan paling penting hingga satu (1) yang dimana kondisi tersebut dinyatakan tidak penting. Komponen maing-masing parameter DRASTIC akan dibagi menjadi beberapa kelas, yang akan berpangruh pada tingkat pencemaran. Rating tersebut akan diberikan dari nilai satu (1) dimana terjadi potensi pencemaran yang rendah, hingga nilai lima (5) dimana terjdi potensi pencemaran sangat tinggi.

\section{Metodologi}

Dalam penetuan daerah kerentanan airtanah menggunakan metode DRASTIC ada beberapa tahapan yang perlu dilakukan diantaranya (Gambar 3) yaitu studi pustaka, dimana pada tahapan ini merupakan kegiatan memahami sesuatu yang berkaitan tentang 
penelitian yang akan dilakukan seperti halnya menentukan tujuan penelitian, mencari informasi tentang kondisi hidrogeologi dan geologi pada daerah penelitian, kegiatan selanjutnya yaitu perijinan pada saat pengambilan data hal ini bertujuan agar stakeholder pada daerah yang kita tuju akan mengerti maksud dan tujuan kedatangan dan manfaat penelitian tersebut, sehingga kita dapat memperoleh data yang diinginkan, mempersiapkan semua kebutuhan yang akan dibawa saat melakukan kegiatan di lapangan, pengumpulan data primer merupakan pengumpulan data utama yang diperoleh dari hasil pengukuran di lapangan yaitu pengukuran kedalaman muka airtanah, pencatatan koordinat sampel sumur, pengukuran elevasi sampel sumur, pengamatan litologi dan kondisi geologi pada daerah sekitar sumur yang diamati, dan pendokumentasian tempat pengambilan sampel, pengumpulan data sekunder merupakan data yang tidak dapat diperoleh saat di lapangan langsung. Data sekunder umumnya didapat dari instansi-instansi pemerintah yang telah melakukan penelitian sebelumnya. Setelah kegiatan lapangan dilaksanakan dan data primer serta sekunder didapatkan, kemudian hal yang dilakukan selanjutnya yaitu pengolahan data tersebut diantaranya pembuatan peta-peta tematik, kemudian pembuatan peta kerentanan airtanah dilakukan dengan cara penginterpolasian dan penjumlahan berbagai macam parameterparameter DRASTIC yang dibutuhkan, seperti peta kedalaman muka airtanah, peta recharge, peta media akuifer, peta media tanah, peta topografi, peta zona vadose, peta konduktivitas hidrolika. Dari berbagai macam peta tematikkemudian dilakukan analisis spasial (tumpah tindih/overlay)seperti persamaan 2.3 didapatkan peta kerentanan airtanah terhadap pencemaran dengan menggunakan metode DRASTIC.

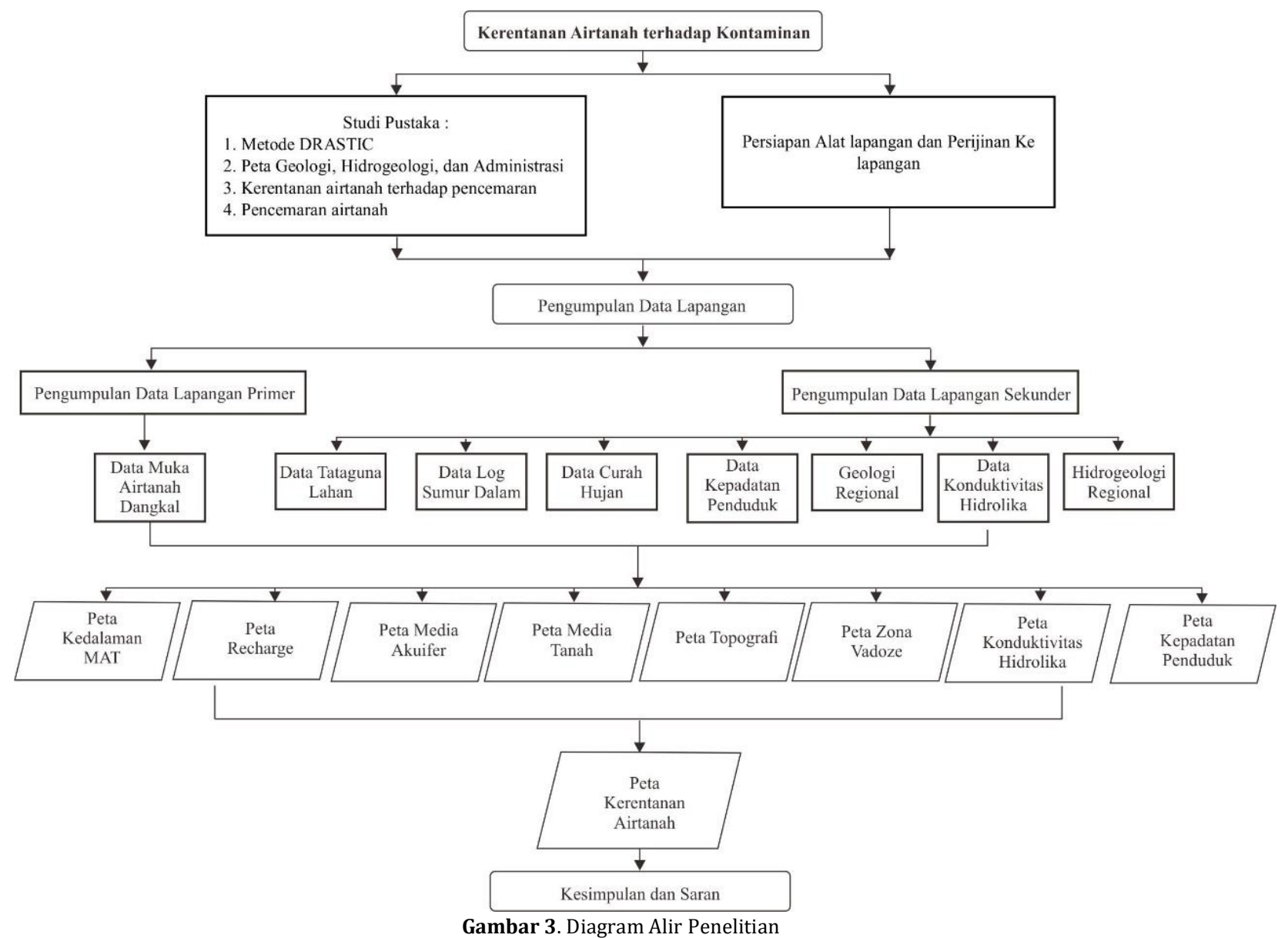

\section{Hasil dan Pembahasan}

\subsection{Depth to water table atau Kedalaman Muka} Airtanah

Dalam melakukan pengukuran langsung di lapangan didapatkan data sebanyak 110 sumur yang tersebar merata di daerah penelitian. Dari hasil pengukuran didapatkan kedalaman muka airtanah terendah yaitu 0,5 m yang terdapat yang terletak di Desa Punduhsari, Kecamatan
Manyaran, Kabupaten Wonogiri, dan muka airtanah terdalam sebesar 9,3 m yang terletak di daerah Desa Tegalsari, Kecamatan Karanggede, Kabupaten Boyolali. Dalam parameter DRASTIC untuk kedalaman muka airtanah dan dampak ke vadoze zone/zona tak jenuh air memiliki nilai pembobotan paling besar dengan nilai bobot 5 dikarenakan kedalaman muka airtanah dam dampak ke vadoze zone sangat mempengaruhi 
kecepatan kontaminan menuju zona jenuh air. Berdasarkan hasil pengukuran di lapangan diperoleh pembagian pembobotan yang terdiri dari 3 kelompok (Tabel 1). Untuk kedalaman 0-1,5 m terdapat di daerah Kabupaten Sragen. Untuk kedalaman menengah yaitu kedalaman 1,5-3 m terdapat di sebagian daerah Kabupaten Klaten, Kota Surakarta, Kabupaten Sukoharjo, dan sebagian Kabupaten Klaten. Kedalaman yang paling dalam yaitu 3-9 m terletak di Kabupaten Boyolali, Kabupaten Karanganyar, dan sebagian Kabupaten Klaten (Gambar 4).

Tabel 1. Perhitungan Skor Kedalaman Muka Airtanah

\begin{tabular}{|c|c|c|c|}
\hline Kedalaman muka airtanah [m] & Rating & Bobot & Skor \\
\hline $0-1,5$ & 10 & 5 & 50 \\
\hline $1,5-3$ & 9 & 5 & 45 \\
\hline $3-9$ & 7 & 5 & 35 \\
\hline \multicolumn{3}{|c|}{ Jumlah } & 130 \\
\hline
\end{tabular}

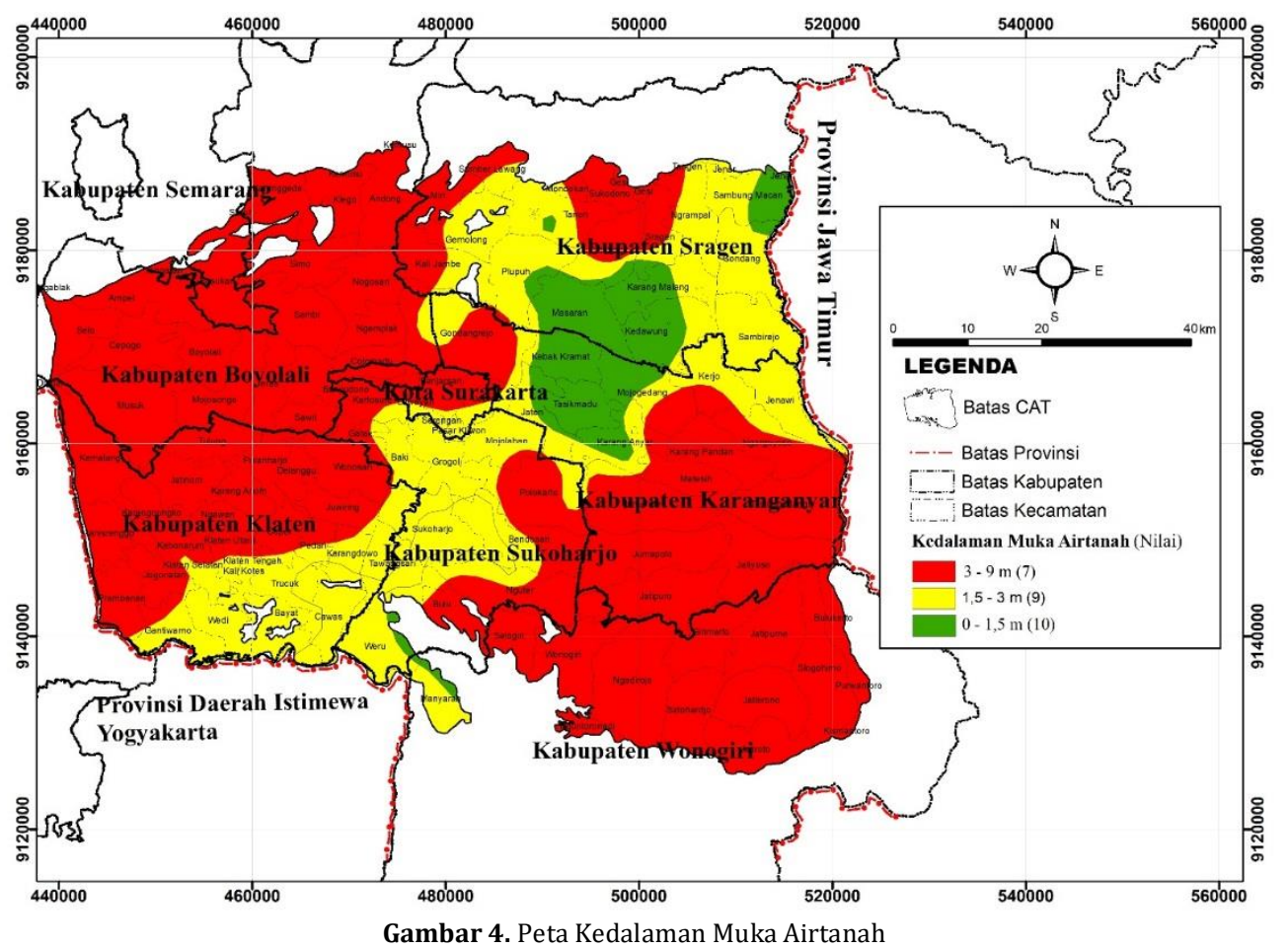

\subsection{Jumlah Recharge}

Jumlah recharge yakni banyaknya air yang masuk bawah permukaan yang biasanya dipengaruhi oleh air hujan. Data curah hujan didapatkan dari data BPS Kabupaten Boyolali, Karamganyar, Klaten, Sragen, Surakarta, Sukoharjo dan Wonogiri (2106). Pada daerah CAT di daerah-daerah bagian timur, dan barat dimana pada daerah tersebut terdapat gunungapi, maka proses infiltrasi berlangsung cukup baik dengan tata guna lahan masih dipergunakan sebagai daerah lindung atau hutan. Namun, pada bagian utara, selatan, dan tengah daerah CAT terjadi perubahan tatagunalahan yang kini diperuntukan sebagai pemukiman dan kawasan industri. Hal ini menyebabkan air hujan yang jatuh menjadi tidak optimal masuk ke bawah permukaan menuju akuifer bebas, sehingga mengakibatkan terjadinya aliran runoff(Gambar 5). Berdasarkan hasil perhitungan recharge didapatkan 2 nilai yaitu 103-178 mm/tahun dan $>254 \mathrm{~mm} /$ tahun (Tabel 2).

Tabel 2. Perhitungan Skor Recharge CAT Karanganyar-Boyolali

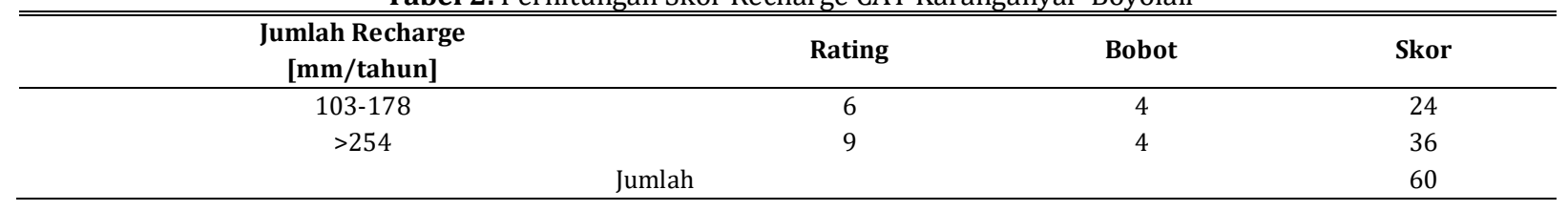




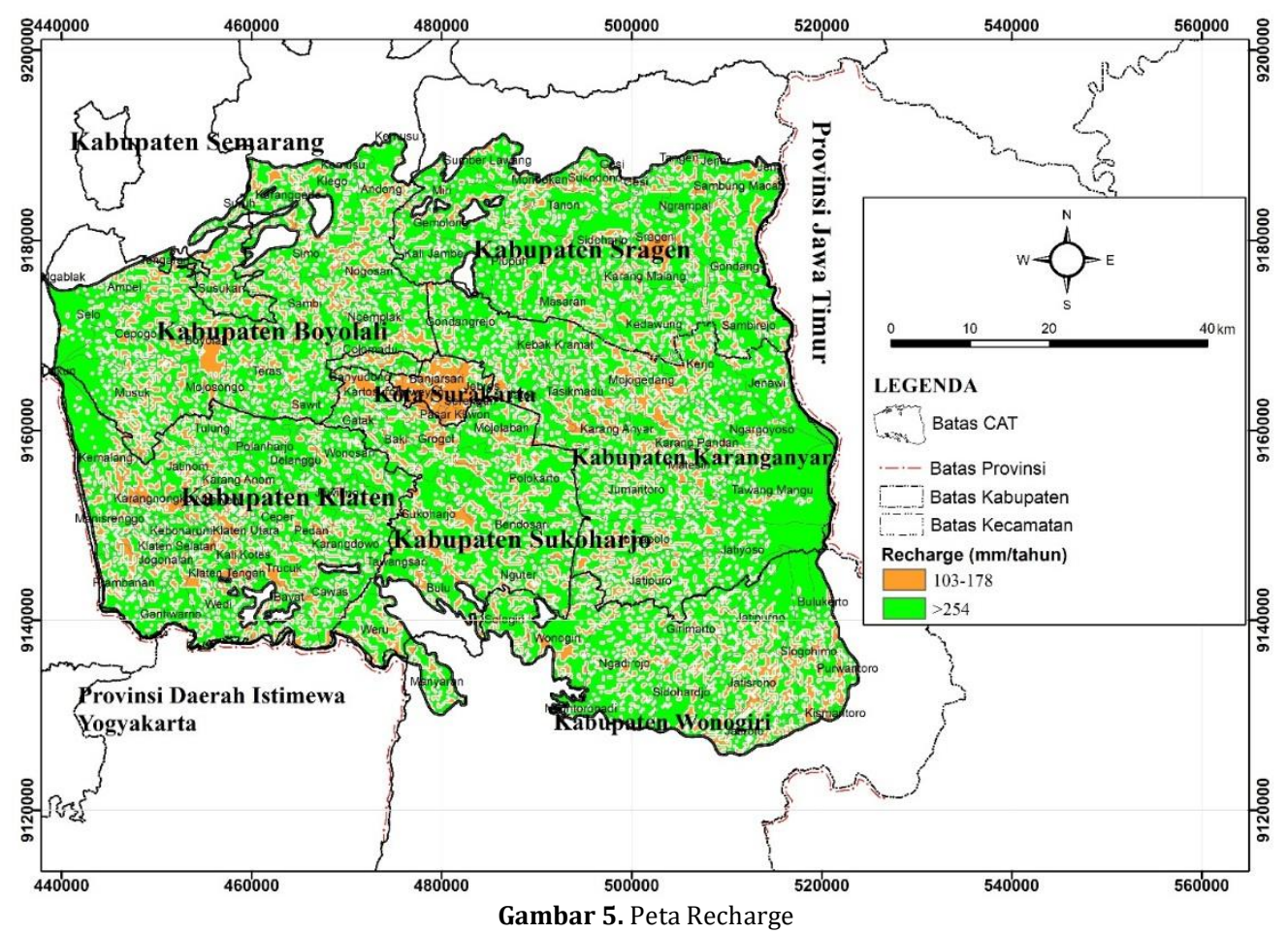

\subsection{Media Akuifer}

CAT Karanganyar-Boyolali tersusun atas berbagai macam produk vulkanik yang dihasilkan dari ketiga gunung api yang berada di area CAT. Untuk daerah yang berdekatan dengan gunung api umumnya memiliki kondisi masif pada batuannya, selain itu juga pada bagian tengah, utara, dan selatan produk yang dihasilkan juga merupakan produk dari hasil gunung api namun kondisinya telah mengalami pelapukan, yang tersusun atas berbagai macam material-material lepasan yang berukuran krikil, pasir, sampai lempung (Gambar 6). Berdasarkan hasil tersebut media akuifer penyusun pada daerah CAT Karanganyar-Boyolali berupa beku lapuk, batupasir, batugamping dan shale, pasir dan kerikil (Tabel 3).

Tabel 3. Perhitungan Media Akuifer CAT Karanganyar-Boyolali

\begin{tabular}{|c|c|c|c|}
\hline Jenis Akuifer & Rating & Bobot & Skor \\
\hline Beku lapuk & 4 & 3 & 12 \\
\hline $\begin{array}{l}\text { Batupasir,batugamping, } \\
\text { dan shale }\end{array}$ & 6 & 3 & 18 \\
\hline Pasir dan kerikil & 8 & 3 & 24 \\
\hline & & & 54 \\
\hline
\end{tabular}

\subsection{Media Tanah}

Media tanah merupakan suatu parameter yang erat kaitannya dengan pengaruh air permukaan yang akan masuk kedalam tanah menuju ke zona akuifer bebas. Parameter ini juga dipengaruhi terhadap jumlah recharge yang akan masuk pada suatu daerah. Hal ini dipengaruhi oleh ruang antar butir dan litologi penyusun pada permukaan. Adanya perbedaan dalam ukuran butir ini membuat terjadi perbedaan pada nilai rating pada parameter ini. Apabila semakin besar ruang butir pada suatu permukaan tanah, maka air hujan atau air permukaan yang masuk nantinya akan cepat menuju ke daerah zona akuifer bebas. Pada daerah penelitian media tanah penyusun terdiri dari LoamsertaNon shrinking dan non agregat lempung (Gambar 7). Sifat dari loam yang didominasi oleh lenau dan lempung, sehingga menghambat laju kontaminan menuju zona jenuh air. Loam ini memiliki skor 2. Non shrinking dan non agregat lempung merupakan kondisi dimana memiliki ruang antar butir yang renggang,sehingga membuat proses filtrasi akan menjadi lebih cepat sehingga kontaminan lebih mudahmencapaizona jenuh air. Media tanah ini memiliki skor10 (Tabel 4).

Tabel 4. Perhitungan Skor Parameter Jenis Media Tanah

\begin{tabular}{|c|c|c|c|}
\hline Jenis Media Tanah & Rating & Bobot & Skor \\
\hline Loam & 1 & 2 & 2 \\
\hline Non shrinking dan non agregat lempung & 5 & 2 & 10 \\
\hline Jumlah & & & 12 \\
\hline
\end{tabular}



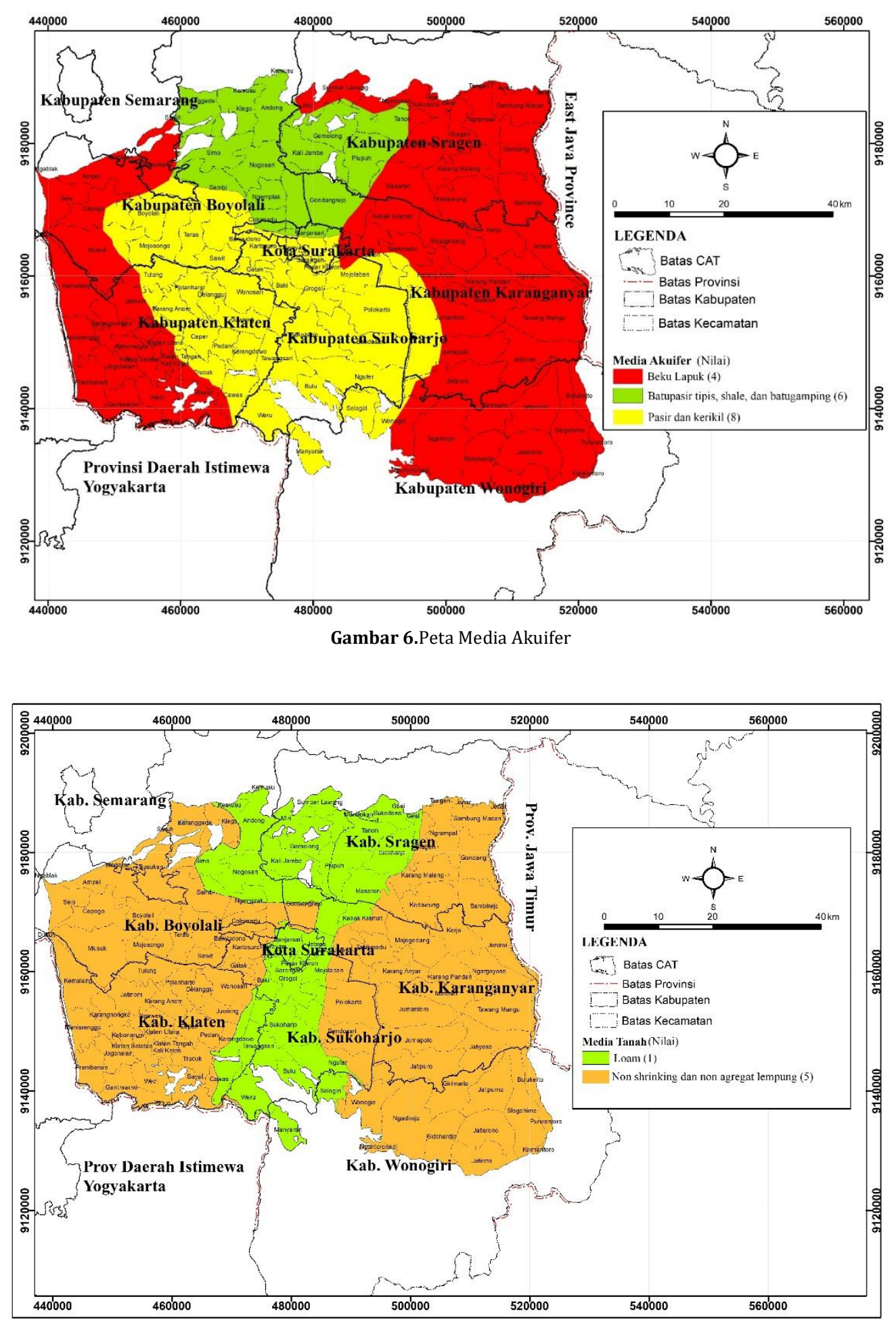

Gambar 7. Peta Media Tanah

\subsection{Topografi}

Pada daerah penelitiandapat dilihat bahwa kemiringan lahan memiliki variasi kemiringan topografi (Gambar 8).Di daerah yang dikelilingi oleh gunung api umumnya memiliki kemiringan lereng yang cukup tinggi yang terletak pada bagian timur, dan barat daerah penelitian, sedangkan daerah dengan kemiringan lahan yang cukup datar terdapat pada tengah daerah penelitian. Dengan demikian dari hasil analisis topografi, umumnya daerah penelitian merupakan daerah yang rentan pada kontaminan karena terletak pada daerah dengan kemiringan lereng 0 6\% (Tabel 5). Daerah dengan kemiringan topografi lebih dari $18 \%$ terletak di daerah sekitar gunung api di bagian timur danbarat. 
Tabel 5. Perhitungan Skor Parameter Topografi

\begin{tabular}{cccc}
\hline \hline Topografi (\% lereng) & Rating & Bobot & Skor \\
\hline $0-2$ & 10 & 9 & 1 \\
$2-6$ & 5 & 9 & 1 \\
$6-12$ & 5 & 3 & 1 \\
$12-18$ & 3 & 3 \\
& & 1 & Jumlah \\
\hline
\end{tabular}

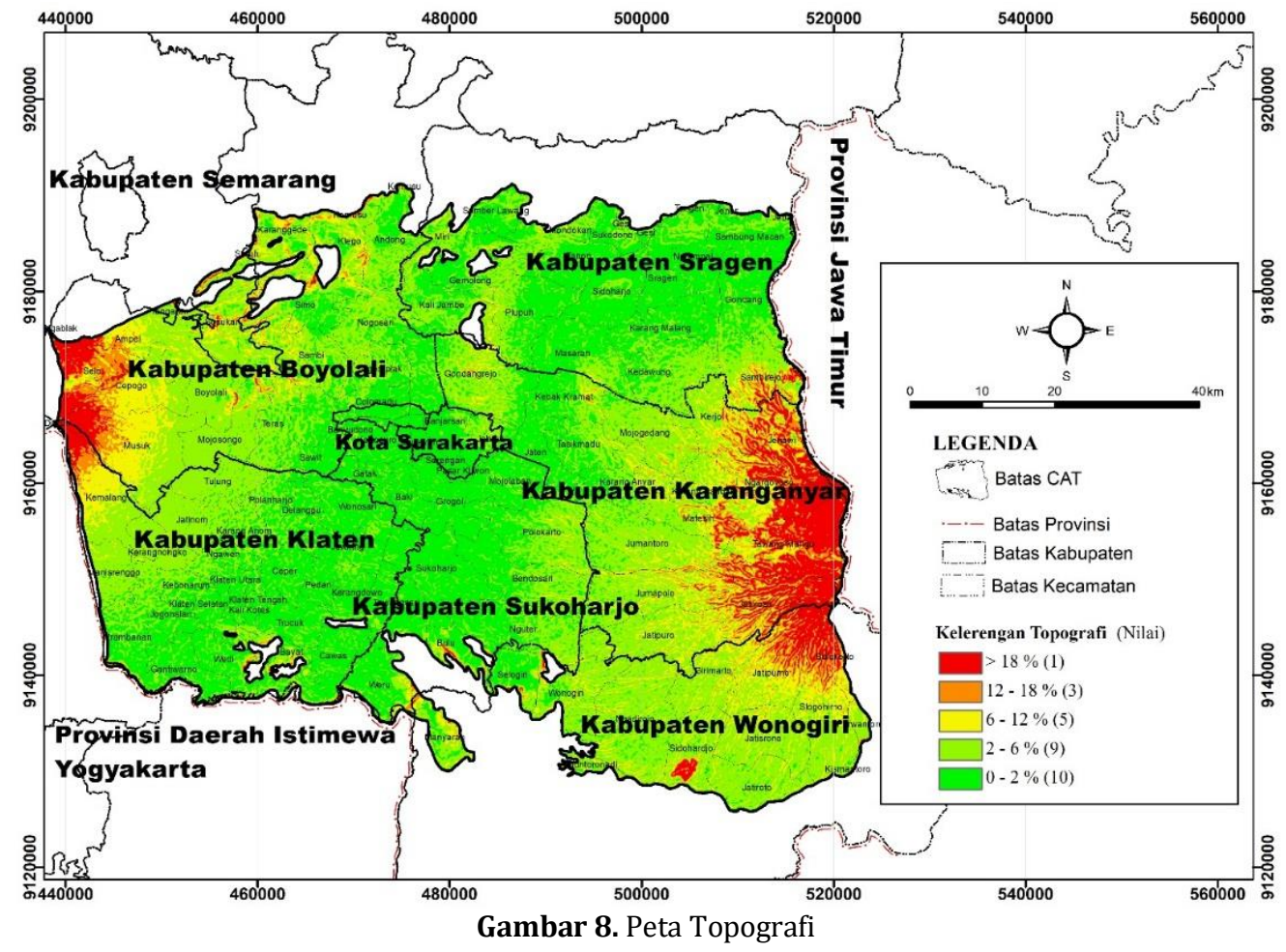

\subsection{Vadoze Zone atau Zona Tak Jenuh Air}

Di daerah penelitian terdapat 2 litologi penyusun zona tak jenuh air, yaitu pasir dan kerikil, kemudian shale dan kerikil dengan lanau dan lempung cukup. Pasir dan kerikil umumnya terletak pada daerah yang dekat gunung api yang memiliki elavasi yang cukup tinggi, edangkan penyusun Shale dan kerikil dengan lanau dan lempung cukup umumnya terdapat pada daerah dataran dan diperkotaan yaitu pada daerah tengah daerah penelitian (Gambar 9).
Parameter ini memiliki nilai bobot 5, dikarenakan parameter ini merupakan salah satu parameter yang dianggap paling berpengaruh terhadap kecepatan kontaminan menuju zona jenuh air. Litologi yang memiliki porositas serta permeabilitas tinggi seperti pasir dan kerikil memiliki skor yang lebih tinggi dibandingkan dengan shale dan kerikil dengan lanau dan lempung cukup karena lebih mempercepat pergerakan kontaminan ke zona jenuh air (Tabel 6).

Tabel 6. Perhitungan Skor Parameter Media Zona Tak Jenuh Air

\begin{tabular}{cccc}
\hline \hline Zona tak Jenuh air & Rating & Bobot & Skor \\
\hline Pasir dan kerikil & 6 & 5 & 30 \\
Shale dan kerikil dengan lanau dan lempung cukup & 4 & 5 & 20 \\
Jumlah & & & 50 \\
\hline
\end{tabular}

\subsection{Konduktivitas Hidrolika}

Nilai konduktivitas sendiri ditentukan dari jenis batuan, ukuran butir, kompaksi batuan, dan susunan butiran (Gambar 10). Berdasarkan hasil di lapangan didapatkan jenis batuan dengan jenis pasir halus, batupasir menengah, dan pasir menengah. Menurut Todd, (1980), pasir halus menengah memiliki nilai konduktivitas sebesar
2,5 m/hari, sedangkan batupasir menengah memiliki nilai konduktivitas sebesar 3,1 m/hari, dan pasir menengah memiliki nilai konduktivitas sebesar $12 \mathrm{~m} /$ hari. Parameter konduktivitas hidrolika memiliki bobot yang cukup besar yaitu 3, karena berpengaruh terhadap kerentanan terhadap kontaminan. Masing-masing skor nilai konduktivitas disajikan di Tabel 6. 
Tabel 7. Perhitungan Skor Parameter Konduktivitas Hidrolika

\begin{tabular}{|c|c|c|c|}
\hline "Konduktivitas hidrolika [m/hari] & Rating & Bobot & Skor \\
\hline $0,86-2,5$ & 2 & 3 & 6 \\
\hline $2,59-6,05$ & 4 & 3 & 12 \\
\hline $8,64-17,18$ & 8 & 3 & 24 \\
\hline & \multicolumn{2}{|c|}{ Jumlah } & 42 \\
\hline
\end{tabular}

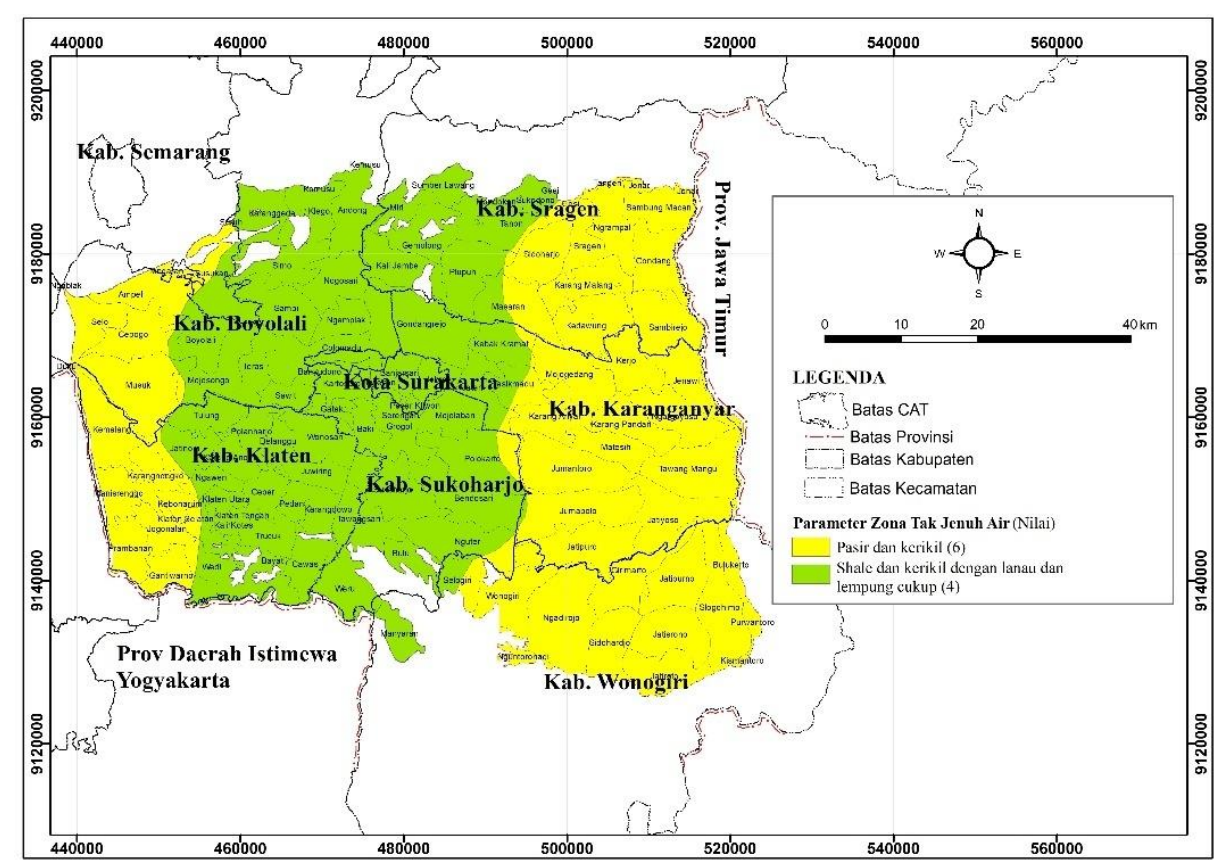

Gambar 9. Peta Zona Tak Jenuh Air

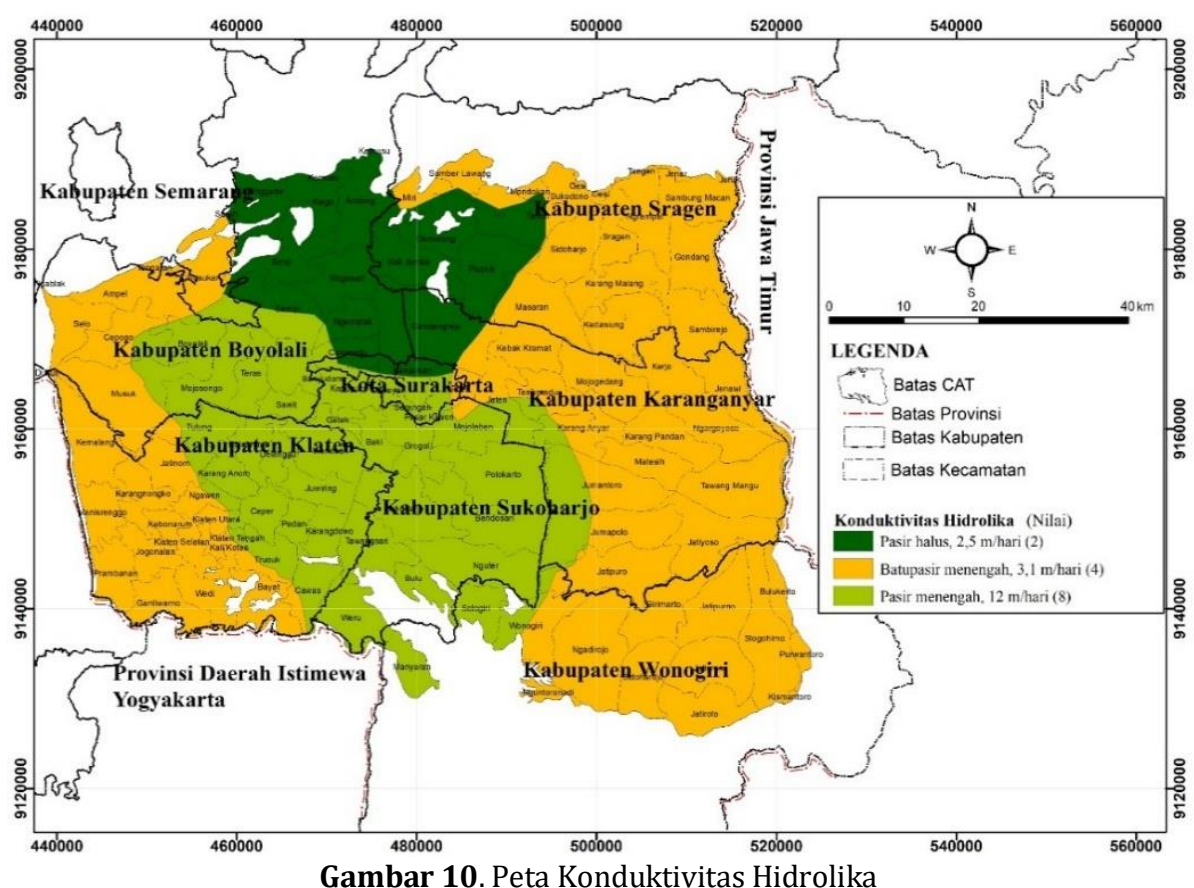

7.8. Kerentanan Airtanah terhadap Pencemaran Metode DRASTIC

Pada penelitian ini peta yang dihasilkan menggunakan metode DRASTIC yang diperoleh dari kegiatan hasil pengukuran di lapangan kemudian diolah menggunakan sistem informasi geografis, sehingga dapat mempermudah untuk melakukan pengolahannya dengan data spasial yang dimiliki. Kemudian pada akhirnya diperoleh nilai-nilai rentang yang sudah ditetapkan dalam metode DRASTIC dan nilai tersebut nantinya akan dimasukan kedalam rumus yang menghasilkan skor akhir, dimana akan diwujudkan dalam bentuk peta zonasi. Dari analisis tumpah tindih semua parameter DRASTIC maka diperoleh hasil DRASTIC Indeks (DI) yang terbagi menjadi 4 
kelas(Gambar 11), yaitu nilai sangat rendah (86100), rendah (101-120), sedang (121-140), dan tinggi (141-148) seperti penelitian yang dilakukan oleh Pacheco, et al (2015).

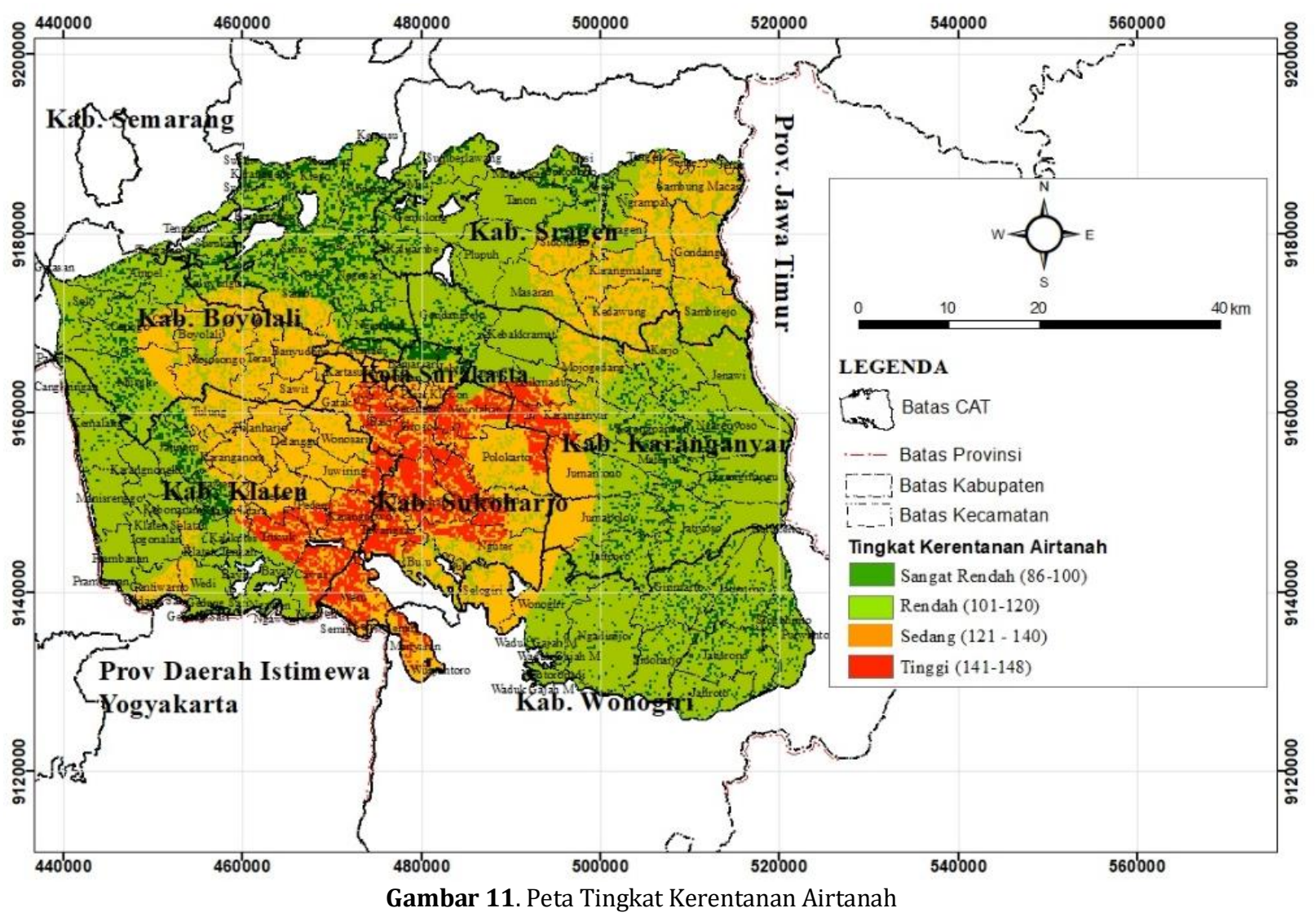

\subsection{Kerentanan Sangat Rendah}

Daerah yang memiliki nilai kerentanan sangat rendah, maka dapat dikatakan daerah tersebut tidak memungkinkan terjadinya kontaminasi pencemaran. Pada daerah lokasi penelitian dengan tingkat DI sangat rendah memiliki kedalaman muka airtanah sebesar 3-9 meter. Semakin dalam muka airtanah maka, kontaminan yang masuk melalui permukaan tanah menuju akuifer bebas akan memerlukan waktu yang cukup lama. Dari paremeter jumlah recharge pada kondisi kerentanan sangat rendah memiliki nilai sebesar $>254 \mathrm{~mm} /$ tahun. Media akuifer yang terdapat pada tingkatan ini termasuk kedalam breksi lapuk, dikarenakan pada umumnya daerah kerentanan sangat rendah terdapat pada daerah pegunungan dimana daerah pegunungan merupakan daerah yang tersusun dari produk vulkanik. Media tanah yang dimiliki pada kondisi ini tersusun atas non shrinking dan non agregat lempung, dimana penyusun permukaan tanah pada kondisi tersebut merupakan material yang tidak solid dan memiliki tingkatan porositas yang baik. Untuk zona Vadoze pada kondisi ini tersusun atas pasir dan krikil, dari kondisi ini dapat dikatakan bahwa kontaminan dapat masuk dengan mudah karena ukuran butirnya berupa pasiran. Konduktivitas hidrolika pada daerah tingkat kerentanan sangat rendah memiliki
2,59-6,05 m/hari. Dengan demikian walaupun penyusun batuan merupakan daerah yang memiliki jenis porositas yang baik, dikarenakan dengan kelerangan yang dimiliki sebesar $>18 \%$ dan merupakan daerah yang baik untuk recharge maka kontaminan yang masuk akan terbawa oleh air hujan yang masuk, daya tinggal kontaminan tidak akan terlalu lama diakibatkan kondisi topografi yang relatif tinggi, dan pada umumya pada daerah dengan tingkat kerentanan sangat rendah sangat sedikit ditemukan industri dan pemukiman. Penyebaran kerentanan sangat rendah banyak ditemukan di Kabupaten Boyolali dan Kabupaten Karanganyar.

\subsection{Kerentanan Rendah}

Dilihat dari kondisi DI pada daerah yang memiliki kerentanan rendah dapat dikatakan bahwa pada daerah tersebut memungkinkan dapat terjadi pencemaran dengan intensitas kecil yang disebabkan pembuangan polutan yang dilakukan secara berkala. Daerah lokasi penelitian dengan tingkat DI rendah memiliki kedalaman muka airtanah sebesar 1,5-9 meter,sehingga kondisi sumur semakin dalam maka kontaminan yang akan masuk menuju akuifer bebas semakin lama. Jumlah recharge pada kondisi kerentanan rendah memiliki nilai sebesar 103-178 mm/tahun dan $>254 \mathrm{~mm} /$ tahun. Media penyusun akuifer yang terdapat pada tingkatan ini 
termasuk kedalam breksi lapuk, dan batupasir tipis, shale, dan batugamping.Dari penyusun akuifer tersebut dapat diketahui bahwa media tersebut merupakan media yang memiliki porositas yang kurang baik oleh sebab dapat menghambat kontaminan yang akan menuju ke zona jenuh air. Media tanah yang dimiliki pada kondisi ini tersusun atas non shrinking dan non agregat lempung, dimana penyusun permukaan tanah pada kondisi tersebut merupakan material yang tidak solid dan memiliki tingkatan porositas yang baik. Untuk zona Vadozepada kondisi ini tersusun atas pasir dan krikil, dan shale dan krikil dengan lanau dan lempung, sehingga kontaminan dapat masuk dengan mudah. Konduktivitas hidrolika pada daerah tingkat kerentanan rendah memiliki nilai 0,86-2,5 m/hari dan 2,59-6,05 $\mathrm{m} /$ hari. Kondisi topografi pada daerah ini memiliki nilai sebesar 2-18 \%. Kondisi kelerengan menunjukkan bahwa kemiringan lereng cukup tinggi,sehingga dapat menghambat kontaminan yang menuju zona jenuh air karena akan lebih dominan mengalir sebagai aliran permukaan/runoff. Penyebaran kerentanan rendah ditemukan di sebagian Kabupaten Boyolali, Kabupaten Sragen, Kabupaten Klaten dan Kabupaten Karanganyar.

\subsection{Kerentanan Sedang}

Pada daerah yang memiliki tingkat kerentanan sedang memiliki sifat yaitu dapat tercemar oleh sebagian polutan yang dibuang secara terus-menerus. Daerah dengan kategori tingkat kerentanan sedang memiliki kedalaman muka airtanah berkisar 0-9 meter. Dengan kondisi kedalaman muka airtanah yang bervariasi ini maka apabila kondisi kedalaman muka kedalaman muka airtanah cukup dangkal maka polutan akan masuk dengan cepat menuju zona jenuh air, dan apabila kedalaman muka airtanah semakin dalam maka polutan akan menuju akuifer bebas memerlukan waktu yang lama . Jumlah recharge yang dimiliki pada tingkat sedang ini memiliki nilai $>254 \mathrm{~mm} /$ tahun. Media penyusun akuifer pada kondisi ini terdiri dari batuan beku lapuk, batupasir tipis, shale, dan batugamping, dan pasir dan kerikil. Media tanah yang dimiliki pada tingkat kerentanan sedang tersusun atas loam dan non shrinking dan non agregat lempung, sedangkan untuk zona vadoze tersusun atas pasir dan krikil, dan shale dan krikil dengan lanau dan lempung cukup, dimana dengan kondisi ini kedua parameter tersebut memiliki ruang antar butir yang tidak terlalu rapat dan memiliki sifat permeabel sehingga mampu membawa kontaminan menuju akuifer bebas dengan cukup mudah dan tidak memerlukan waktu yang lama. Kondisi kelerengan topografi berkisar 0$6 \%$,sehingga daerah ini termasuk daerah yang relatif datar, mengakibatkan kontaminan lebih mudah menuju zona jenuh air. Kerentanan sedang banyak tersebar di Kabupaten Boyolali, Kabupaten Sragen, sebagian Kabupaten Karanganyar, dan Kabupaten Klaten.

\subsection{Kerentanan Tinggi}

Pada kondisi ini daerah yang memiliki tingkat kerentanan tinggi akan dapat tercemar oleh semua polutan, akan tetapi ada beberapa yang tidak dapat yaitu dengan kondisi yang memerlukan daya serap tinggi dan mudah berubah-ubah secara tiba-tiba. Daerah dengan kategori tingkat kerentanan tinggi memiliki kedalaman muka airtanah berkisar 0-3 meter, sehingga kontaminan lebih cepat masuk menuju zona jenuh air. Jumlah recharge yang dimiliki pada tingkat kerentanan tinggi ini memiliki nilai 103-178 mm/tahun serta $>254$ $\mathrm{mm} /$ tahun. Media penyusun akuifer pada kondisi ini tersusun atas batupasir tipis, shale, dan batugamping, dan pasir dan kerikil, dan Pasir dan krikil, dengan penyusun material tersebut memiliki tingkat porositas yang cukup baik, sehingga kontaminan yang akan masuk menuju akuifer bebas juga akan semakin cepat. Media tanah pada kondisi ini tersusun atas loam dan non shrinking dan non agregat lempung, sedangkan untuk zona vadoze tersusun shale dan krikil dengan lanau dan lempung cukup, dimana dapat dilihat kedua parameter tersebut memiliki ruang antar butir yang tidak terlalu rapat dan memiliki sifat permiabel yang cukup baik oleh karena itu air yang membawa kontaminan akan masuk menuju akuifer bebas dengan cukup mudah dan tidak memerlukan waktu yang lama. Kondisi kelerengan topografi berkisar 0-6\% dapat dikatakan pada daerah ini termasuk daerah yang landai, sehingga memungkinkan polutan akan masuk menuju akuifer bebas lebih cepat. Kerentana tinggi banyak tersebar di wilayah Kota Surakarta dan Kabupaten Sukoharjo.

\section{Kesimpulan dan Saran}

Berdasarkan hasil kerentanan yang diperoleh dari metode DRASTIC, pada daerah CAT Karanganyar-Boyolali didapatkan 4 tingkat kerentanan diantaranya kerentanan sangat rendah, rendah, sedang, dan tinggi.

a. Tingkat kerentanan sangat rendah bersifat tidak memungkinkan terjadinya kontaminasi pencemaran. Saran yang dapat dilakukan yaitu dengan melakukan pemantauan berkala tentang penggunaan lahan secara tepat guna.

b. Tingkat kerentanan rendah bersifat dapat tercemar dengan intensitas kecil disebabkan oleh pembuangan polutan yang dibuang secara berkala. Saran yang dapat dilakukan yaitu pemantauan lahan secara periodik dan pemantauan penggunaan pupuk dikalangan 
petani, dengan takaran yang tidak melebihi batas.

c. Tingkat kerentanan sedang bersifat akan dapat tercemar oleh polutan namun pencemaran tersebut terjadi oleh sebagian polutan yang dibuang secara terus-menerus dan berkala. Saran yang dapat dilakukan yaitu perlu adanya sosialisasi ke masyarakat tentang pembuangan dan pengelolaan limbah yang berdekatan dengan sumur gali, dan melakukan pemantauan kuantitas dan kualitas airtanah secara periodik yang bertujuan untuk mengetahui dan mengontrol tingkat pencemaran yang terjadi.

d. Tingkat kerentanan tinggi bersifat dapat tercemar oleh semua polutan, akan tetapi ada beberapa polutan yang tidak dapat terserap yaitu dengan kondisi yang memerlukan daya serap tinggi dan mudah berubah-ubah secara tiba-tiba. Saran yang dapat dilakukan yaitu melakukan pembuatan sumur pantau agar dapat diketahui kualitas dan kuantitas airtanah pada daerah tersebut, dan pembuatan peraturan daerah tentang tata cara pembuatan pengelolaan dan konstruksi pembuangan limbah.

\section{DAFTAR PUSTAKA}

Aller, L., Bennet, T., Lehr, J.H., Petty, R.J. 1987.DRASTIC: A Standardized System For Evaluating Ground Water Pollution Potential Using Hydrogeological Settings, EPA.

Ananda, Mufti., Andre, P.H., Endang P. 2016.Studi Kerentanan Polusi Airtanah Di Tempat Pembuangan Sampah Ngijo Kecamatan Karangploso Kabupaten Malang Dengan Menggunakan Metode DRASTIC.Malang : Jurusan Teknik Pengairan Fakultas Teknik Universitas Brawijaya.

Badan Pusat Statistik (BPS) Kabupaten Boyolali.2016.Kabupaten Boyolali Dalam Angka, Boyolali : Badan Pusat Statistik.

Badan Pusat Statistik (BPS) Kabupaten Karanganyar. 2016.Kabupaten Karanganyar Dalam Angka, Karanganyar : Badan Pusat Statistik.

Badan Pusat Statistik (BPS) Kabupaten Klaten. 2016. Kabupaten Klaten Dalam Angka, Klaten : Badan Pusat Statistik.

Badan Pusat Statistik (BPS) Kabupaten Sragen. 2016.Kabupaten Sragen Dalam Angka, Sragen : Badan Pusat Statistik.

Badan Pusat Statistik (BPS) Kota Surakarta. 2016.Kota Surakarta Dalam Angka, Kota Surakarta : Badan Pusat Statistik.

Badan Pusat Statistik (BPS) Kabupaten Sukoharjo. 2016. Kabupaten Sukoharjo Dalam Angka, Sukoharjo : Badan Pusat Statistik.
Badan Pusat Statistik (BPS) Kabupaten Wonogiri. 2016.Kabupaten Wonogiri Dalam Angka, Wonogiri : Badan Pusat Statistik.

Badan Perencanaan dan Pembangunan Daerah Provinsi Jawa Tengah.2010.Peta Rencana Tata Ruang Wilayah Provinsi Jawa Tengah Tahun 2010-2030. Semarang : Badan Perencanaan dan Pembangunan Daerah.

Civita, M.V. 2010.The combined approach when assessing and mapping groundwater vulnerability to contamination.J. Water Resourceand Protection, 2, 14-28.

Danaryanto, H. 2005.Air Tanah Di Indonesia dan Pengelolaannya.Jakarta : Departemen ESDM.

Djaeni, A. 1982.Peta Hidrogeologi Indonesia Lembar Yogyakarta Skala 1:250.000. Bandung : Direktorat Geologi Geologi Tata Lingkungan.

Ferreira, J.P.L., A.G. Catharina, Diamantio, Henriques, M.J. 2005.Assesing Aquifer Vulnerability to Seawater Intrusion Using GALDIT Metod, Part 1 Aplication to the Potuguse Aquifer of Monte Gordo, Four Inter Colloq, Hydrol.

Foster, S., dan Hirata, R. 1988.Groundwater Pollution Risk Assessment a methodology using available data.Peru : World Health Organization.

Gogu, R.C., dan Dassargues, A. 2000. Current trends and future challenges on groundwater vulnerability assessment using overlay and index metod.Jurnal Environmental Geologyi, 549-59.

Hadi, S. 2006.Penilaian Kerentanan Airtanah di Bandung. Buletin Geologi Tata Lingkungan, 16(2), 13-23.

Harter, T., dan Walker, L.G. 2001.Booklet: Assessing Vulnerability of Groundwater. California Departement of Health Services.

Hatori, C.A. 2008.Studi Kerentanan Air Laut di Kota Semarang (Tesis).Yogyakarta : Universitas Gadjah Mada, tidak dipublikasikan.

Kesuma, Destha A. 2017.Studi Kerentanan Airtanah Terhadap PencemaranDi Cekungan Airtanah (CAT) Salatiga (Tesis).Semarang : Universitas Diponegoro.

Pacheco, F.A.L., Pires, L.M.G.R., Santos, R.M.B., dan Fernandes, L.F.S. 2015.Factor Weighting In DRASTIC Modeling. Science of the Total Environment 505 (2015) 474-486.

Peraturan Menteri ESDM Nomor 2 Tahun 2017 Tentang Cekungan Airtanah.

Putranto, T.T. 2013.Hydrological and numerical groundwater flow model in Semarang, Indonesia, Germany: RWTH Aachen University.

Rahaningmas, F. S. 2017.Kerentanan Airtanah Terhadap Pencemaran Di Kota Wonosari dan Sekitarnya Kabupaten Gunung Kidul Daerah Istimewa Yogyakarta (Tesis).Yogyakarta : Universitas Gadjah Mada, Tidak dipublikasikan.

Sampurno, dan Samodra, H. 1997.Peta Geologi Skala 1:100.000 Lembar Ponorogo, Jawa Tengah. Bandung : Pusat Penelitian dan Pengembangan Geologi. 
Stempvort, D.V., Ewert, L., dan Wassenaar, L. 1993.Aquifer Vulnerability Index; A GisCompatible Metod for Groundwater Vulnerability Mapping, Canadian Water Resources Journal, 18.1, 25-37.

Sukardi, dan Budhitrisna, T. 1992.Peta Geologi Skala 1:100.000 Lembar Salatiga, Jawa Tengah.Bandung : Pusat Penelitian dan Pengembangan Geologi.

Surono, B. Toha, dan I. Sudarno. 1992.Peta Geologi Skala 1:100.000 Lembar Surakarta-Giritronto Jawa Tengah.Bandung : Pusat Penelitian dan Pengembangan Geologi.
Todd, D.K. 1980.Groundwater Hydrogeology, $2^{\text {nd }}$ ed.New York: John Wiley \& Sons Inc.

Widyastuti, M., Sudarto, N., Komang, A. 2006.Pengembangan Metode 'DRASTIC' Untuk Prediksi Kerentanan Airtanah Bebas Terhadap Pencemaran Di Sleman.Majalah Geografi Indonesia Vol 20, No 1, ISSN 0125-1790.

Yuslihanu, F. 2015.Studi Kerentanan Airtanah Terhadap Kontaminan Menggunakan Metode Drastic Di Kota Pekalongan, Jawa Tengah (Skripsi).Semarang : Universitas Diponegoro. 